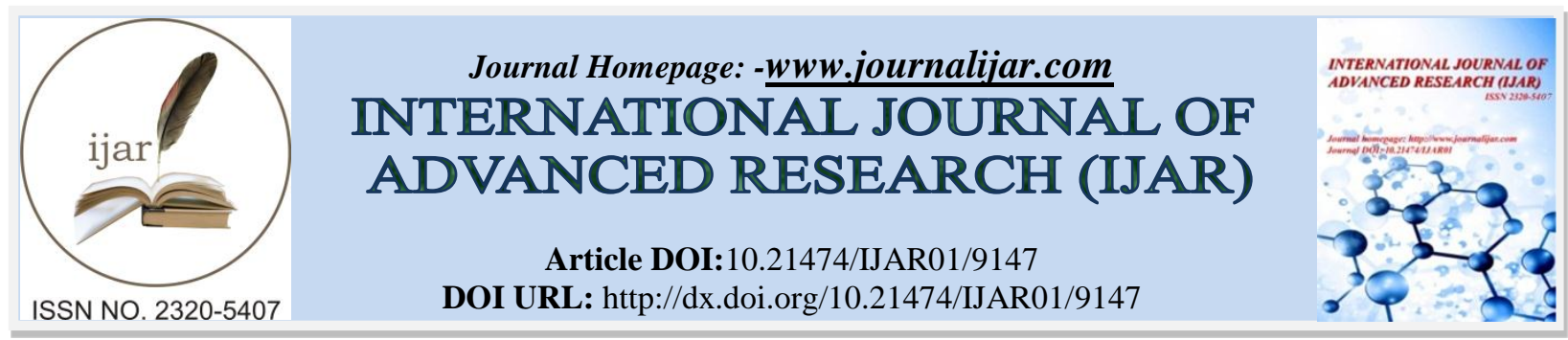

RESEARCH ARTICLE

\title{
PERIODONTAL STATUS OF PATIENTS WITH CLEFT PALATE (CL) AND UNILATERAL CLEFT LIP, PALATE AND ALVEOLUS (UCLPA)-A COMPARATIVE STUDY.
}

\author{
Dr. Munaza Shafi And Dr. Nawal Khan.
}

Department of Dentistry, SKIMS Medical College, Bemina, Srinagar.

\section{Manuscript Info}

\section{Manuscript History}

Received: 24 March 2019

Final Accepted: 26 April 2019

Published: May 2019

Key words:-

Periodontal status, Cleft lip, Cleft palate, Plaque index.

\begin{abstract}
Background:To evaluate and compare the oral hygiene and periodontal status in children with cleft palate $(\mathrm{CP})$ and unilateral cleft lip, palate and alveolus.

Method: 60 patients were taken for the study. They were divided into two groups, group 1 consists of cleft palate patients and group 2 consisted of unilateral cleft lip, palate and alveolus patients. From all the patients, the following parameters were recorded: Plaque Index (PI, Silness and Loe), Sulcus Bleeding Index (SBI, Muhlemann and Son), Probing Pocket Depth (PPD), Clinical Attachment Level (CAL).

Results: Prevalence of periodontal disease is high among patients with cleft lip, alveolus and palate than in cleft palate as indicated by all parameters.

Conclusion: In this study, patients with cleft lip, palate and alveolus had poor oral hygiene and periodontal status compared with patients with cleft palate.
\end{abstract}

Copy Right, IJAR, 2019,. All rights reserved.

\section{Introduction:-}

Facial clefts are ranked as the most common congenital malformations. Cleft lip and palate (CLP) are common congenital deformities that often affect speech, hearing, and facial esthetics and may at times lead to airway compromise ${ }^{[1]}$ CLP have an impact on multiple developmental and functional processes. Children and adults with cleft lip and palate are at increased risk for the development of gingival and periodontal diseases, which are associated with both anatomic defects and long-term orthodontic treatment. ${ }^{[2,3]}$ Anatomic defects, delays in the formation and eruption of teeth, problems with orthodontic movement, and the presence of prosthetic restorations all contribute to reductions in bone levels in the areas adjacent to cleft regions. Dental and arch segment irregularities, orthodontic appliances, and persisting soft tissue folds before palatoplasty as well as the presence of scar tissue after

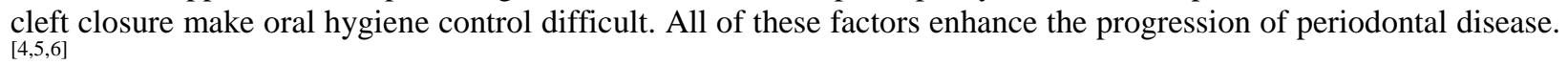

Even before the complete closure, the soft tissue folds making it difficult to access the areas with conventional cleaning techniques and may serve as a habitat for putative pathogens. This increases the risk of enhancing the intraoral translocation of pathogens, thereby increasing the risk of periodontal infection. ${ }^{[7]}$ High incidence of bleeding on probing and plaque in individuals with cleft lip, palate and alveolus (CLAP) was reported, after the analysis of progression rate. ${ }^{[8]}$ Cumulative periodontal destruction is more in teeth with long supracrestal connective tissue attachment and which is adjacent to the cleft. ${ }^{[9]}$

Corresponding Author:-Dr. Munaza Shafi.

Address:-Department of Dentistry, SKIMS Medical College, Bemina, Srinagar. 
Evaluation of periodontal conditions is often neglected or insufficiently documented, since the patients' major problems are related to reconstructive treatment and quality of life. ${ }^{[10,11]}$ As a result, there are very few studies regarding the periodontal status in cleft patients. The aim of the study was to evaluate the periodontal status and oral hygiene in growing patients with bilateral cleft lip and palate and to compare the results with other studies.

\section{Materials And Methods:-}

The present study was conducted in 60 patients with age ranging from 10-18 years, who reported to the department of dentistry SKIMS. They were divided into two groups: Group 1 consisted of 30 patients with Cleft palate (CP) and Group 2 consisted of 30 patients with unilateral Cleft Lip Alveolus and Palate (UCLAP).

\section{Inclusion criteria}

1. Subjects having purely congenital cleft lip/cleft palate and those having cleft lip, alveolus and palate that was not operated.

2. Systemically healthy subjects.

\section{Exclusion criteria}

1. History of any systemic disease.

2. Oral prophylaxis underwent 6 months prior to the study.

3. Only the permanent teeth were considered for periodontal examination.

The dental examinations were conducted in a dental chair using a mouth mirror and Williams probe. The following parameters were recorded:

1. Plaque Index (PI, Silness and Loe 1964)

2. Sulcus Bleeding Index (SBI, Muhlemann H.R. and Son S.1971)

3. Probing Pocket Depth (PPD)

4. Clinical Attachment Level (CAL)

\section{Results:-}

Among the 60 study subjects, 39 were males and 21 were females. Tables1, 2, 3and 4 show the mean difference of values between different parameters of two groups.

Table 1:-Comparison of mean plaque value index between two groups

\begin{tabular}{|l|l|l|l|}
\hline & Group 1 & Group 2 & p value \\
\hline Plaque index & $1.28 \pm 0.36$ & $1.59 \pm 0.35$ & $<0.0001$ \\
\hline
\end{tabular}

Table 2:-Comparison of mean sulcus bleeding index scores between the groups

\begin{tabular}{|l|l|l|l|}
\hline & Group 1 & Group 2 & p value \\
\hline SBI Scores & $0.09 \pm 0.11$ & $0.21 \pm 0.22$ & 0.01 \\
\hline
\end{tabular}

Table 3:-Comparison of mean probing pocket depth (in $\mathrm{mm}$ ) between two groups

\begin{tabular}{|l|l|l|l|}
\hline & Group 1 & Group 2 & p value \\
\hline Probing pocket depth & $2.23 \pm 0.68$ & $2.54 \pm 0.59$ & 0.03 \\
\hline
\end{tabular}

Table 4:-Comparison of mean clinical attachment level (in $\mathrm{mm}$ ) between the groups

\begin{tabular}{|l|l|l|l|}
\hline & Group 1 & Group 2 & p value \\
\hline CAL & $2.44 \pm 0.75$ & $2.75 \pm 0.54$ & 0.02 \\
\hline
\end{tabular}

\section{Discussion:-}

There are only a few studies on periodontal conditions in growing patients with clefts. In fact the periodontal status may have important implications in the comprehensive treatment of these individuals. ${ }^{[12,13]}$ Alveolar process deficiency has a negative impact on soft tissue appearance, causing functional and aesthetic problems in this area. Additionally, combined deficiencies of hard and soft tissues are particularly difficult to treat. ${ }^{[14,15,16,17]}$ Most authors are consistent that patients with clefts are at an increased risk for the development of periodontal disease and carious lesions. However, the data are still limited. Patients with clefts are at high risk of progress of periodontal disease if no supportive periodontal therapy is provided in their early childhood. It has already been presented that adult 
patients with clefts, high plaque score and gingival inflammation had more periodontal tissue destruction. Moreover, the risk of periodontal disease and the level of tissue disorders increased with age. ${ }^{[13]}$

Thus, it may be inferred from this study that subjects with CLPA are more prone for periodontal lesions. In case of neglected oral hygiene, these subjects are predisposed to periodontal disease in the direct vicinity of clefts, leading to premature pathological loosening of teeth. Thus, intensive oral hygiene measures taken by these subjects along with early interdisciplinary treatment are an effective way to prevent extensive periodontal disease.

\section{Conclusion:-}

From this study, it can be concluded that patients with UCLPA had a poor oral hygiene and periodontal status when compared with cleft palate patients. It seems essential to include regular periodontal examination and prophylaxis into comprehensive treatment in cleft patients. Further assessment of a large-sized group is necessary to establish the preventive protocol in multidisciplinary treatment.

\section{References:-}

1. Friel MT, Starbuck JM, Ghoneima AM, Murage K, Kula KS, Tholpady S, et al. Airway obstruction and the unilateral cleft lip and palate deformity: Contributions by the bony septum. Ann Plast Surg 2015; 75:37-43.

2. Quirynen M, Dewinter G, Avontoodt P, Heidbuchel K, Verdonck A, Carels C. A split mouth study on periodontal and microbiological parameters in children with complete unilateral cleft lip and palate. J Clin Periodontol. 2003; 30:49-56.

3. Lages EM, Marcus B, Pordeus IA. Oral health of individuals with cleft lip,cleft palate, or both. Cleft Palate Craniofac J. 2004; 41:59-63.

4. Teja Z, Persson R, Omnell ML. Periodontal status of teeth adjacent to nongrafted unilateral alveolar clefts. Cleft Palate Craniofac J. 1992;29:357- 362.

5. Wong F, King N. The oral health of children with clefts: a review. Cleft Palate-Craniofac J. 1998;35:248-254.

6. Costa B, Lima JE, Gomide MR, Rosa OP. Clinical and microbiological evaluation of the periodontal status of children with unilateral complete cleft lip and palate. Cleft Palate Craniofac J. 2003; 40:585-589.

7. Quirynen M, Soete DM, Steenberghe DV, The intra-oral translocation of periodontopathogens jeopardises the outcome of periodontal therapy. J Clin Periodonto. 2001; 28:499-507.

8. Bragger U, Schurch E, Salvi G, Wyttenbach TV, Lang NP, Periodontal conditions in adult patients with cleft lip, alveolus and palate. Cleft Palate Craniofac J.1992 29:179-85.

9. Boloor Vinita, Thomas Biju, Comparison of periodontal status among patients with cleft lip, cleft palate, and cleft lip along with a cleft in palate and alveolus. J Indian Soc Periodontol. 2010 14(3):168-72.

10. Esper LA, Sbrana MC, Ribeiro IW, de Siqueira EN, de Almeida AL. Analysis of gingival components of smile and degree of satisfaction in individuals with cle! lip and palate. Cleft Palate Craniofac J. 2009;46(4):381-387.

11. Kapagiannidis D, Kontonasaki E, Bikos P, Koidis P.Teeth and gingival display in the premolar area during smiling in relation to gender and age. J Oral Rehabil. 2005; 32(11):830-837.

12. Andlin-Sobocki A, Eliasson LA, Paulin G. Periodontal evaluation of teeth in bone grafted regions in patients with unilateral cleft lip and cleft palate. Am J Orthod Dentofacial

13. Orthop. 1995; 107(2); 144-152.

14. Salvi GE, Bragger U, Lang NP. Periodontal attachment loss over 14 years in cleft lip, alveolus and palate. J Clin Periodontol. 2003; 30:840-845.

15. Paradowska-Stolarz A, Dubowik M, Szeląg J, Kawala B.Dental anomalies in the incisor-canine region in patients with cleft lip and palate - literature review. Dev Period Med. 2014; 18(1):66-69.

16. 15.da Silva Filho OG, Teles SG, Ozawa TO, Filho LC. Secondary bone graft and eruption of the permanent canine in patients with alveolar clefts: Literature review and case report.Angle Orthod. 2000; 70:174-178.

17. Dudkiewicz Z. Surgical treatment of unilateral cleft lip and palate-own experience, Dev Period Med. 2014; 18(1):33-37.

18. Brudnicki A, Piwowar W, Cudziło D, Sawicka E. Complete unilateral cleft lip and palate operated on by means of the one-stage method - own experience. Dev Period Med.2014; 18(1):38-43. 